\title{
PERHITUNGAN ANGKA LEMPENG TOTAL BAKTERI PADA TELUR AYAM RAS
}

\author{
Surahmaida $^{1)}$ dan Sri Nurhatika ${ }^{2)}$ \\ ${ }^{1}$ Staf Pengajar D-III Farmasi Akademi Farmasi Surabaya \\ ${ }^{2}$ Staf Pengajar Biologi FMIPA Institut Teknologi Sepuluh November Surabaya \\ Email: fahida1619@gmail.com
}

\begin{abstract}
Poultry farm chicken eggs is one of the favorite food for society besides meat and fish, because it is highly nutritious, versatile and cheaper than other eggs. The sample of this research uses 8 (eight) samples of poultry farm chicken eggs. This study aims to determine the quality of poultry farm chicken eggs microbiology based on the total plate count of bacteria. The results showed average the total plate count of bacteria on 8 chicken eggs is $10^{4}$ $\mathrm{CFU} / \mathrm{ml}$. This shows that the results still qualified the standard defined by BPOM that is $10^{7}$ $\mathrm{CFU} / \mathrm{ml}$ and its mean poultry farm chicken eggs is safe for consumption.
\end{abstract}

Keywords: Poultry farm chicken eggs, Total Plate Count of Bacteria

\section{PENDAHULUAN}

Salah satu bahan makanan yang praktis digunakan dan tidak memerlukan pengolahan yang sulit adalah telur. Telur merupakan bahan pangan yang digemari masyarakat karena sarat akan protein, lemak tak jenug, vitamin dan mineral yang dibutuhkan tubuh manusia (Warsito, 2015; Mulza dkk., 2013). Selain itu, telur adalah salah satu sumber protein hewani yang memiliki rasa yang lezat, mudah dicerna dan harganya lebih terjangkau dibandingkan dengan protein hewani lainnya.

Telur yang beredar di pasaran bermacam-macam, seperti telur ayam ras, telur ayam kampung, telur bebek dan telur puyuh. Namun, umumnya masyarakat cenderung mengkonsumsi telur ayam ras. Hal ini dikarenakan telur ayam ras lebih mudah didapatkan dan harganya juga lebih murah.

Telur rentan rusak/mudah pecah dan memiliki daya simpan yang pendek (Nurhadi, 2012). Pada saat penyimpanan, telur ini bisa terjadi kerusakan secara fisik, kimia maupun biologis (Hardianto dkk., 2012). Umumnya kerusakan telur secara biologis, terjadi karena masuknya bakteri. Masuknya bakteri ini berasal dari kotoran yang menempel pada kulit telur, kotoran dari feses, tanah atau suatu bahan yang mengandung bakteri. Selain itu, bakteri dapat masuk ke dalam kulit telur yang retak atau menembus kulit telur melalui poripori telur (Lubis dkk., 2012). 
Sebagai bahan pangan yang bergizi tinggi, maka telur harus memenuhi standar kesehatan yang telah ditetapkan sehingga aman dikonsumsi oleh masyarakat. Berdasarkan latar belakang tersebut, maka perlu dilakukan pengujian kualitas mikrobiologi telur ayam ras berdasarkan angka lempeng total bakteri.

\section{METODE PENELITIAN}

\section{Alat dan Bahan}

Alat yang digunakan dalam penelitian ini adalah autoklaf, inkubator, cawan petri, tabung reaksi, erlenmeyer, pengaduk, jarum ose, bunsen dan mikropipet.

Bahan yang digunakan adalah delapan telur ayam ras yang diperoleh dari peternakan ayam ras, nutrient agar (NA), $\mathrm{NaCl}$, alkohol $95 \%$, aquades.

\section{Sterilisasi alat dan bahan}

Sebelum penelitian, maka semua alat dan bahan (NA) yang akan digunakan disterilisasi dengan menggunakan autoklaf pada suhu $121^{\circ} \mathrm{C}$ selama 15 menit pada tekanan 1,5 atm.

\section{Pengambilan Sampel Telur}

Sampel penelitian ini adalah telur sebanyak 8 buah yang diambil secara acak dari tiap kandang battery ayam.

\section{Cara memecah telur}

Sampel telur dibersihkan dengan air kran yang mengalir, kemudian diusap dengan alkohol. Ujung telur yang lancip diarahkan ke bawah lalu didekatkan ke mulut erlenmeyer, kemudian dipecah dengan benda tumpul secara hatihati. Isi telur dalam erlenmeyer dikocok dengan pengaduk hingga rata (homogen).

\section{Pengujian angka lempeng total bakteri}

Pengujian ALT bakteri ini berdasarkan prosedur Hastuti (2015). Dimasukkan $1 \mathrm{ml}$ suspensi telur dengan mikropipet steril ke dalam $9 \mathrm{ml} \mathrm{NaCl}$ untuk memperoleh pengenceran $10^{-1}$, dengan cara yang sama dibuat seri pengenceran $10^{-2}$, $10^{-3}$ dan $10^{-4}$.

Lalu secara aseptis dimasukkan NA hangat (suhu $45^{\circ} \mathrm{C}$ ) ke dalam cawan petri yang telah berisi $1 \mathrm{ml}$ masing-masing dari suspensi pengenceran tersebut. Cawan petri digoyang dengan hatihati membentuk angka delapan supaya media dan sampel tersebar merata (homogen). Diinkubasi pada suhu $37^{\circ} \mathrm{C}$ selama $1 \times 24$ jam. Diamati dan dihitung jumlah koloni bakteri yang tumbuh pada media agar yang mempunyai $30-300$ koloni.

\section{Perhitungan angka lempeng total bakteri}

Perhitungan jumlah koloni yang tumbuh dilakukan setelah diinkubasi 1x24 jam, baik itu koloni 
tunggal dan koloni yang bergabung dianggap satu koloni bakteri. Jumlah bakteri yang memenuhi persyaratan untuk dihitung berkisar antara 30-300 koloni. Bila jumlah koloni $<30$, dianggap terlalu sedikit (tidak memenuhi syarat), sedangkan bila jumlah koloni $>300$ juga dianggap terlalu banyak (tidak memenuhi syarat). Adapun cara perhitungan ALT adalah sebagai berikut:

\section{ALT bakteri $=$ jumlah koloni $x \frac{1}{\text { faktor pengenceran }}$}

\section{HASIL PENELITIAN}

Tujuan dari dilakukan pengenceran pada ALT ini adalah untuk mengurangi jumlah kandungan mikroorganisme dalam sampel sehingga nantinya dapat diamati dan diketahui jumlah mikroorganisme secara spesifik sehingga didapatkan perhitungan koloni yang tepat (Fardiaz, 1993).

Metode angka lempeng total yang digunakan dalam penelitian ini adalah metode agar tuang (pour plate method). Kelebihan dari metode agar tuang adalah koloni mikroorganisme tumbuh di dalam dan permukaan media agar, sehingga memudahkan dalam perhitungan jumlah koloni bakteri (Tortora et al., 2002).

Dari hasil penelitian, didapatkan ALT bakteri pada 8 sampel telur ayam ras dapat dilihat pada Tabel 1.

Tabel 1. Hasil Angka Lempeng Total Bakteri pada delapan sampel telur ayam ras

\begin{tabular}{|c|l|c|}
\hline Sampel Telur & ALT Bakteri & Standar POM \\
\hline 1 & $3,8878 \times 10^{4}$ & \\
\hline 2 & $14,4940 \times 10^{4}$ & \\
\hline 3 & $13,9630 \times 10^{4}$ & \multirow{3}{*}{ Angka Lempeng Total $=10^{7}$} \\
\hline 4 & $23,7100 \times 10^{4}$ & \\
\hline 5 & $25,6660 \times 10^{4}$ & \\
\hline 6 & $3,2370 \times 10^{4}$ & \\
\hline 7 & $22,1710 \times 10^{4}$ & \\
\hline 8 & $20,6880 \times 10^{4}$ & \\
\hline &
\end{tabular}


Pada Tabel 1 di atas, menunjukkan ALT pada delapan sampel telur ayam ras kurang dari $10^{7} \mathrm{CFU} / \mathrm{ml}$. Sehingga, hasil pengujian total cemaran mikroba pada telur ayam ras ini memenuhi standar kesehatan makanan yang telah ditetapkan BPOM, dimana standar ALT adalah $10^{7} \mathrm{CFU} / \mathrm{ml}$ (Anonimous, 1989).

Hasil pengujian ALT bakteri pada telur disamakan dengan ALT daging karkas tanpa tulang beku. Hal ini dikarenakan telur seperti daging giling merupakan hasil pencampuran kontaminan permukaan di seluruh bahan, dan jumlah mikroba sama dengan yang diperoleh untuk daging giling (Jawetz et al., 1984).

\section{KESIMPULAN}

Hasil angka lempeng total bakteri pada telur ayam ras adalah $10^{4} \mathrm{CFU} / \mathrm{ml}$. Nilai ALT tersebut memenuhi standar kesehatan BPOM, dimana standar ALT telur adalah $10^{7} \mathrm{CFU} / \mathrm{ml}$.

\section{DAFTAR PUSTAKA}

Anonimous. 1989. Petunjuk Standar

Kesehatan Makanan. Balai Laboratorium Kesehatan. Surabaya.

Fardiaz, S. 1993. Analisis

Mikrobiologi Pangan. PT. Raja

Grafindo Persada. Jakarta.

Hardianto, G.K. Suarjana dan M.D.

Rudyanto. 2012. Pengaruh Suhu dan Lama Penyimpanan Terhadap Kualitas Telur Ayam Kampung Ditinjau dari Angka Lempeng Total Bakteri. Indonesia Medicus Veterinus. Fakultas Kedokteran Hewan. Universitas Udayana. 1(1):72.

Hastuti, S.U. 2015. Penuntun Praktikum Mikrobiologi. UMM Press. Malang.

Lubis, H.A., G.K. Suarjana dan M.D. Rudyanto. 2012. Pengaruh Suhu dan Lama Penyimpanan Terhadap Kualitas Telur Ayam Kampung Terhadap Jumlah Escherichia coli. Indonesia Medicus Veterinus. Fakultas Kedokteran Hewan. Universitas Udayana. 1(1): 145 .

Mulza, D.P., Ratnawulan dan Gusnedi. 2013. Uji Kualitas Telur Ayam Ras Terhadap Lamanya Penyimpanan Berdasarkan Sifat Listrik. Pillar of Physics. Universitas Negeri Padang. 1(2):111.

Nurhadi, M. 2012. Kesehatan Masyarakat Veteriner. Yogyakarta: Gosye Publishing. Tortora, G.J., Funke, B.R, and L.C. Christine. 2002. Microbiology: An Introduction. Pearson Education Inc. San Fransisco. USA.

Warsito, H., Rindiani., Fafa, N. 2015. Ilmu Bahan Makanan Dasar. Yogyakarta: Nuha Medika, Cetakan Pertama. 